\title{
Socioeconomic and territorial dynamics in Breves-Marajó (Pa), post- decline of madeira activity
}

\section{Socioeconomic and territorial dynamics in Breves-Marajó (Pa), post-decline of madeira activity}

\author{
Odair José Aragão Alves ${ }^{1}$, Christian Nunes da Silva ${ }^{1 *}$, João Marcio Palheta da Silva ${ }^{1}$
}

\begin{abstract}
The present article aims to analyze the economy of the municipality of Breves, in Brazilian State of Pará, from the decline of logging activity, which was considered the main economic base of the city, linked to trade and service provision activities, as fundamental to the upkeep and subsistence of Breves' population, and diversification of that production, against the decay of logging business. Such activities shape the local economy in our times, employing a considerable portion of Breves' labor, including many of which were idle, because of the unemployment generated by the closing of timber companies. Aiming to broaden the discussion on the topic, it were conducted literature searches, as well as both qualitative and quantitative interviews, which contributed to the characterization of the local economy and to verify how the current economic activity is able to ensure the livelihood of the local population.
\end{abstract}

Keywords: Economic dynamics. Commerce. Provision of services.

\section{RESUMO}

O presente artigo tem como finalidade analisar a economia do município de Breves, no Estado do Pará, a partir do declínio da atividade madeireira, considerada a principal base econômica do município, associada às atividades de comércio e de prestação de serviços, como basilares para a manutenção e para a subsistência da população brevense, e a diversificação desta produção, frente à decadência da atividade madeireira. Tais atividades, hodiernamente, modelam a economia local, empregam uma considerável parcela da mão de obra brevense, inclusive, muitos dos que ficaram ociosos, em virtude do desemprego gerado pelo fechamento das empresas madeireiras. Visando a ampliar a discussão sobre o referido tema, foram realizadas pesquisas bibliográficas, bem como entrevistas qualiquantitativas, o que contribuiu para a caracterização da economia local e, com isto, de modo a verificar de que forma a atual atividade econômica é capaz de garantir a subsistência da população local.

Palavras-chave: Dinâmica econômica. Comércio. Prestação de serviços.

${ }^{1}$ Group on Territory and Environment Production in the Amazon (GAPTA/CNPq), Federal University of Pará (UFPA), Belém, Pará, Brazil.

1 *Email: cnsgeo@yahoo.com.br. 


\section{INTRODUCTION}

For decades, both economic and productive manufacture processes of the municipality of Breves, in the Brazilian State of Pará, had been linked to numerous activities that generate employment and income for the population, but it was by the logging activity that the city signed up between the main centers of plant extraction, which had wood as the insertion product in the markets, in different spheres, since from the second half of the 20th century, the municipality was already establishing commercial relations with other parts of Brazil, by the offering of timber and rice products, also emphasizing the production of latex, which also boosted the local economy.

Some social, territorial and, above all, economic transformations will be analyzed in this work, since the changes brought by the advent, apex and collapse of the timber activity shaped the structure of that aspects and caused evident transformations in Breves' scenario. In this sense, it was plausible to understand all the consequences of timber activity decline.

Therefore, this work was based on quantitative and qualitative research methods, in which several actors were interviewed, including businessmen who were directly and indirectly linked to the timber industry. The fieldwork analyzes made in Breves / Marajó region, in the State of Pará, are related to both the context of the timber production process and the representation of its socio-spatial organization, especially, in the urban area of Breves, from the decay of this activity, including the main consequences of the closing of wood production and processing industries, highlighting the importance of the civil service and government welfarism in the dynamics and development of the other commercial activities of the municipality.

Considered by the locals as the activity that promoted the major economic dynamics, throughout the history of Breves, the timber industry represented the local development for the city, its integration to other parts of Brazil and abroad, in addition to having favored the emergence and strengthening of other types of business that were considered only additional to the livelihood of city inhabitants. The way how logging activity was being carried out in the Brazilian Amazon, since the 1980s, with its predatory characteristics, caused many concerns, which has aroused the eyes of many bodies and institutions, including, in worldwide. Undoubtedly, this exploitation form 
showed disparity, regarding the use of timber forest resources developed by riverside communities.

Until the 1960s, logging activity was quantitatively very small and concentrated in the lowland forests of the great rivers of Pará, due to the easiness in the use of rafts for runoff (VERÍSSIMO et al., 2002, p. 15), and, historically, the various types of wood extracted from the forest areas on Breves' countryside met, basically, to the foreign market. According to Leão (2014):

In Breves, through the connections between forests, rivers and ports, a range of products entered and left the city, boosting local commerce. Many products, such as rubber, wood, rice, oil seeds, wild animal skins and tropical fruits, crossed the straits of Breves [...] (LEÃO, 2014, p. $57)$.

By the arrival of companies, for the exploration of the Amazon, attracted by tax incentives, the trade with foreign countries was strengthened. This can be noticed by the construction of a customs port and, especially, the presence of cargo ships in the city. These events contributed for the occurrence of changes in the forms of usage of timber resources, which are extended to beyond the municipality's operating areas. Soon, both socioeconomic and territorial changes started to become evident, among which, migrations, caused by job searches.

With the decline of logging activity in Brief, the municipality has another economic base, centered in trade and service provision activities, which are run by government welfare and, especially, the civil service, especially for health and education services, which are responsible for absorbing a large portion of local working population. This process reveals the presence of another business modeling in Breves' economic scenario, because unemployment fosters new logics of generating jobs and income for the population, given that many people seek for other ways to ensure their livelihoods, returning to exercise activities that were stagnant, during the time of logging, such as agriculture and fishing.

The population colonies and the unions absorb a large quantity of members, in order to ensure rights to farmers and fishermen, for example. With the consequent increase and the expansion of both commercial and service provision activities, the municipal revenue gains new numbers and some investments started to become visible in 
urban landscape, yet that these activities present themselves with deficit, in terms of advances in infrastructure, which can result in improvements in people's quality of life.

\section{THE WOOD ISSUE IN PARÁ AND ITS DECADENCE (2000-2015)}

Presenting itself in different ways, the devastation of the Amazon rainforest, by agriculture, livestock and mining projects and programs, has a negative direct impact on many societies. This is accentuated, from the 1960s, by the opening of several economic exploitation fronts, especially, by timber companies, in accordance with the federal laws, which sought to promote regional development. Thus, several programs were implemented, aiming to achieve this goal, through models, which were based on incentive policies, such as the fiscal.

Incentive taxes are still targeting of controversy, by the literature. Considering the case of Breves municipality, these instruments financed the deforestation of the Brazilian Amazon. However, according to Hurtiene (2005, p. 20), "Government development programs carried out in the last 40 years in the Amazon, despite being insufficient, have profoundly changed the economic, demographic and ecological structure of the region". According to Castro (2007), among the programs and economic exploitation fronts, livestock is still responsible for most of the deforestation, because of the growing areas of land occupied by it. In the same way, for Margulis (2003), in terms of deforestation extension, livestock is the most important activity and agriculture in principle has little effect on the deforestation.

Considering this scenario, Fearnside (2003) state that the trend continues to be the uninterrupted advance of the deforestation process.

Over the past few decades, there has been a continuous modification of the Amazon rainforest, which has led to an important loss of forest cover, given the extent of the land affected. States, such as Maranhão, Mato Grosso, Pará and Rondônia, have had their land use greatly altered, with a reduction in biodiversity [...]. (CASTRO, 2005, p. 6).

According to Verissimo, Lima and Lentini (2002), for more than three centuries, logging activity occurred sporadically in Pará. However, in recent decades, both Pará and Mato Grosso states have been appearing constantly among the biggest loggers in the Amazon Forest, exchanging first and second places. Despite of this fact, since 1960, logging business has been standing out in Pará, with regard to exploration and 
export, being the second most important activity of the state, since mining maintains the leadership of extractive activities.

The wood exportation gives an expressive contribution to the economy of the State, making up a considerable part of Pará's Gross Domestic Product (GDP) and making this activity quite significant, within the dynamics of the State economy. However, for a long time, this scenario has brought profound changes to the exploration process, in which the reduction in deforestation rates beckons to a crisis, which was conceived by environmental laws and decrees, as well as nongovernmental organizations actions, in addition to result in strong pressure by both national and international institutions and, according to Menezes and Guerra (1998), the suspension of permits for the exploitation of mahogany and ferrule, between the years 1996 and 1998.

The implementation of conservationist forestry policies resulted in a considerable decrease in the number of companies operating in the activity (Figure 1). However, these measures came belatedly, contributing to many people to act illegally for survival reasons.

Figure 1 - Evolution on deforestation rate reduction in Legal Amazon

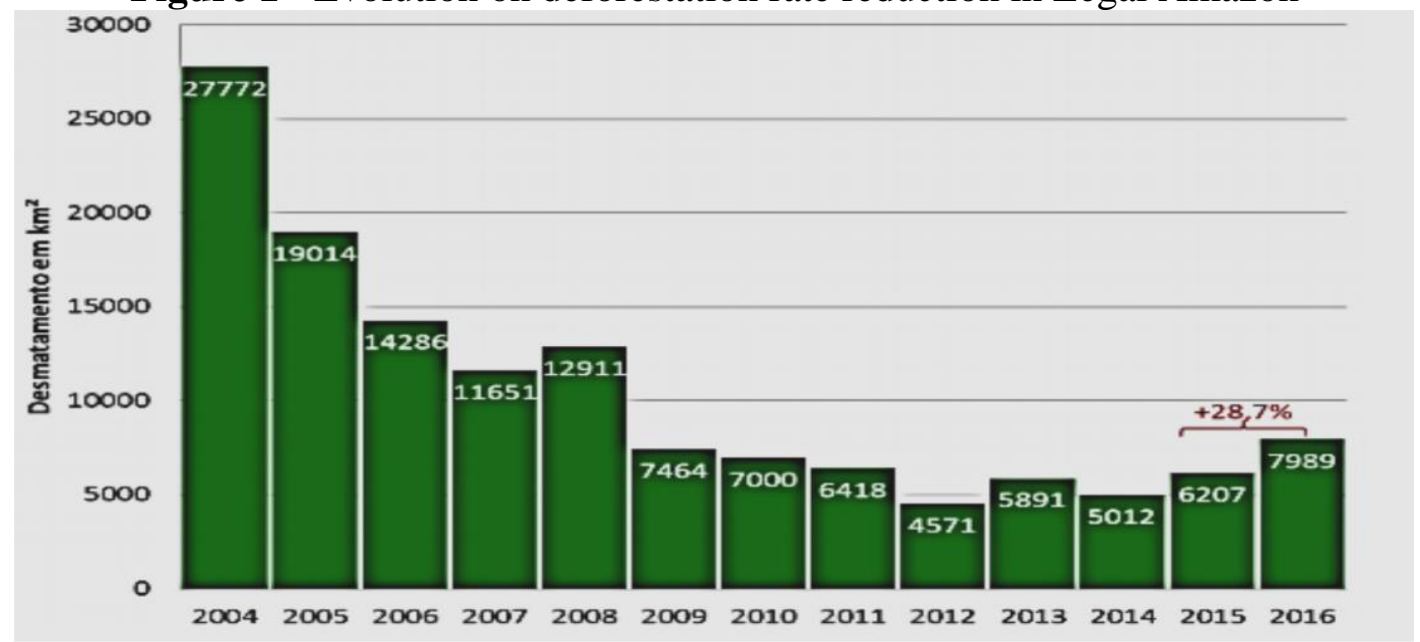

Source: From IPAM and PRODES / INPE data (2018)

Accompanying the reduction in deforestation rates, the number of companies focused on the timber exportation started to decline in 2008 , directly reflecting on the socioeconomic conditions of the population, as well as in political, economic and structural conditions of the Pará State. The logging activity, which had always performed an strategic role for the regional development, followed the path of decay, and the results were immediately perceived in exportation rates. According to AIMEX (2017), the 
exportation dynamics of the State of Pará assumed the following condition, in recent years (Figure 2):

Figure 2 - Pará State total wood exportation values*

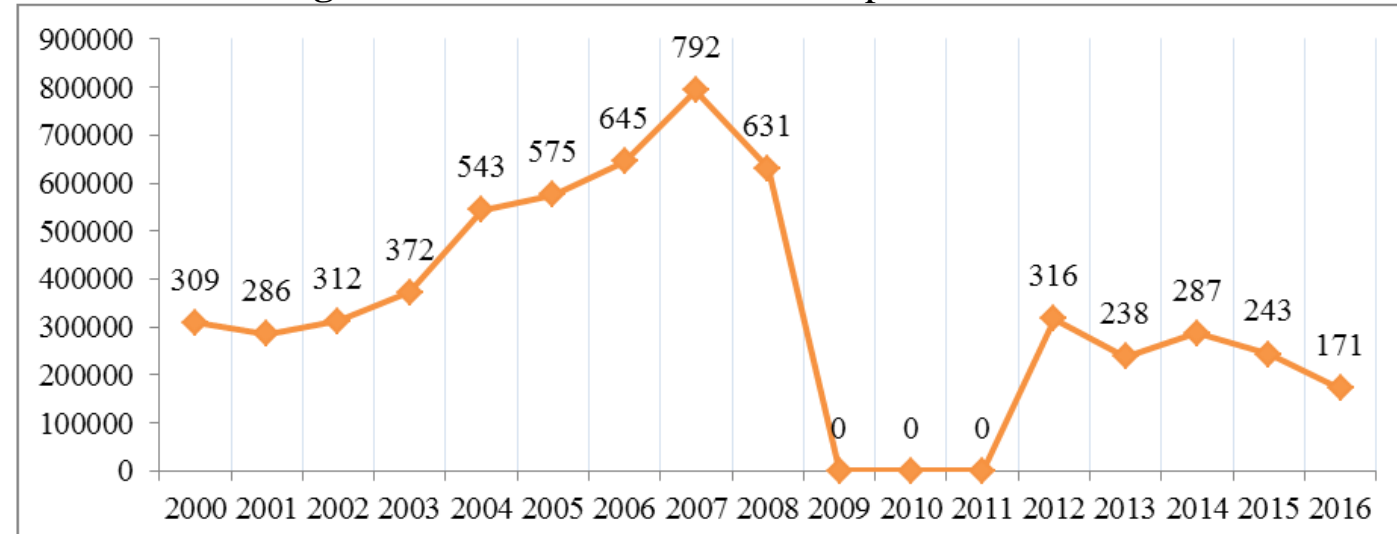

* Data for the years 2009, 2010 and 2011 were not available, during the period of this research.

Source: Adapted by Odair Alves, from AIMEX / DECEX data (2017)

In 1998, there were 1,210 companies $^{2}$ that were part of the 24 logging poles of the State of Pará (distributed in five logging zones: Central, Estuarine, East, West and South). According to Veríssimo, Lima and Lentini (2002):

[...] these centers housed 676 timber companies, of which 602 were sawmills, 43 were rolling mills and 31 were plywood factories. In addition, there were 534 circular sawmills located mainly in the estuary and lower Amazon regions (VERÍSSIMO; LIMA; LENTINI, 2002, p. 23).

With this, the timber forest resources of Pará started to be exploited on a large scale, especially, the exportation ones, placing the State among the main exporters of wood from the Brazilian Amazon (Figure 3). According to Pará's the exportation records, wood is second only to mining products. From these practices, companies start to show several problems, causing impacts on the environment, fomenting governmental and environmental protection institutions to define and seek regulatory instruments regarding the uses of this natural resource and the others.

\footnotetext{
${ }^{2}$ According to Veríssimo, Lima and Lentini (2002), the types of timber companies were classified into sawmills, laminators, plywood plants and circular sawmills (these ones were equipped with circular saws and Induspan horizontal mills).
} 
Figure 3 - Amazon deforestation rate by state, especially in 2013 (in $\mathrm{km}^{2}$ )

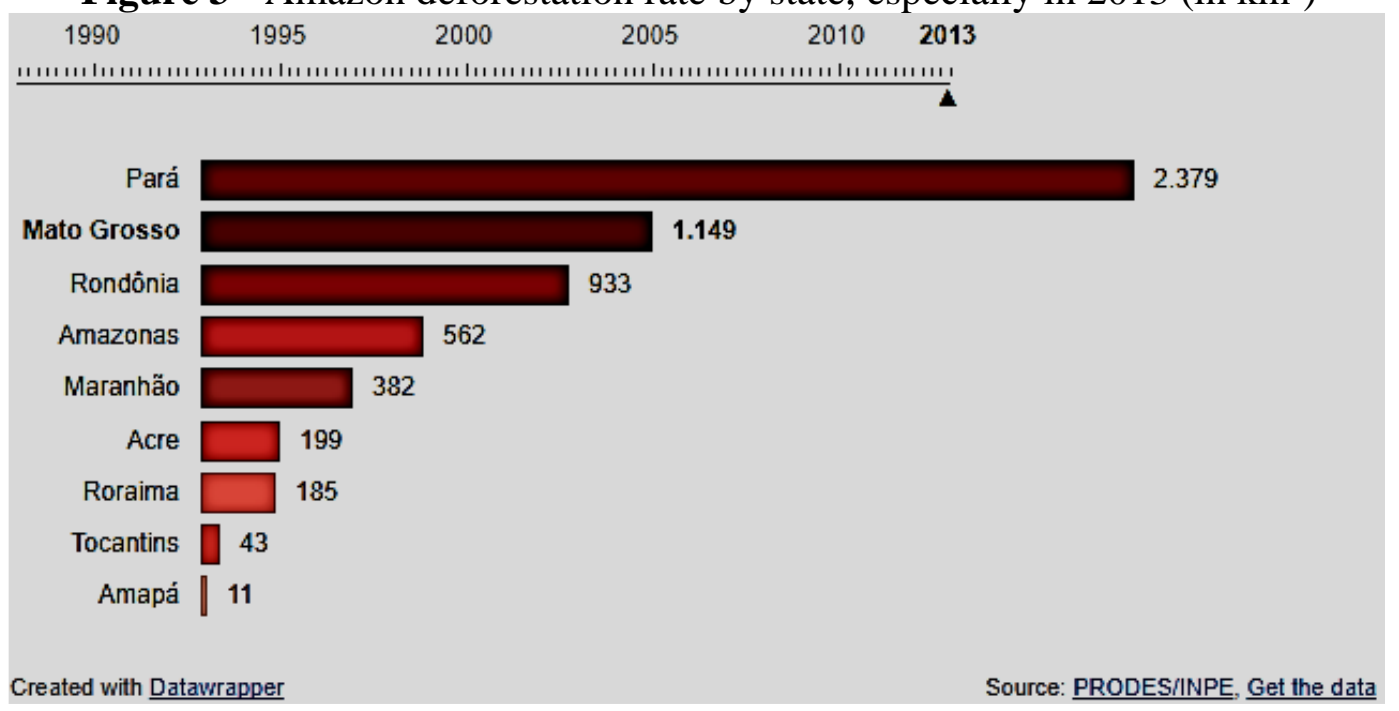

Source: O ECO website (available at: http://www.oeco.org.br/blogs/oeco-data/27897-matogrosso-e-para-os-campeoes-de-desmatamento-na-amazonia/)

The logging activity causes major impacts, which reflects directly in environmental, social, territorial and cultural aspects, changing landscapes and the way of living of many people. Likewise, other exploratory activities, such as mining, agriculture and livestock, also promote changes in these features. According to the Association of Timber Exporting Industries of the State of Pará (AIMEX), between 2001 and 2008 the exportation rates had a great evolution, accompanied by the deforestation rates. In this regard, Castro (2005) states that:

Deforestation rates were still poorly known, but research results showed data that confirmed what was already known: the disaster of the natural wealth loss in exchange for almost nothing, from the point of view of regional development, such as hardwood exported in logs and the waste of other logs felled identically, or the appreciation in the land market by planting pasture (CASTRO, 2005, p. 12).

It is important to notice that not only timber companies are primarily responsible for the massive deforestation of the Amazon Forest. In addition to these, other forms of use and occupation of the Amazon soil cause great deforestations, such as livestock and plantation agriculture. On the one hand, strong national and international pressure on this form of land use by these companies contribute to, from 2008, many timber exporters companies cease to exist in Pará (Figure 4) and, on the other hand, deforested areas are converted into land that is generally used for agriculture, livestock, urbanization or structures that will be part of physical logistics, such as roads, bridges, etc. 
Figure 4 - Total of timber exporting companies in the State of Pará, from 2001 to 2016

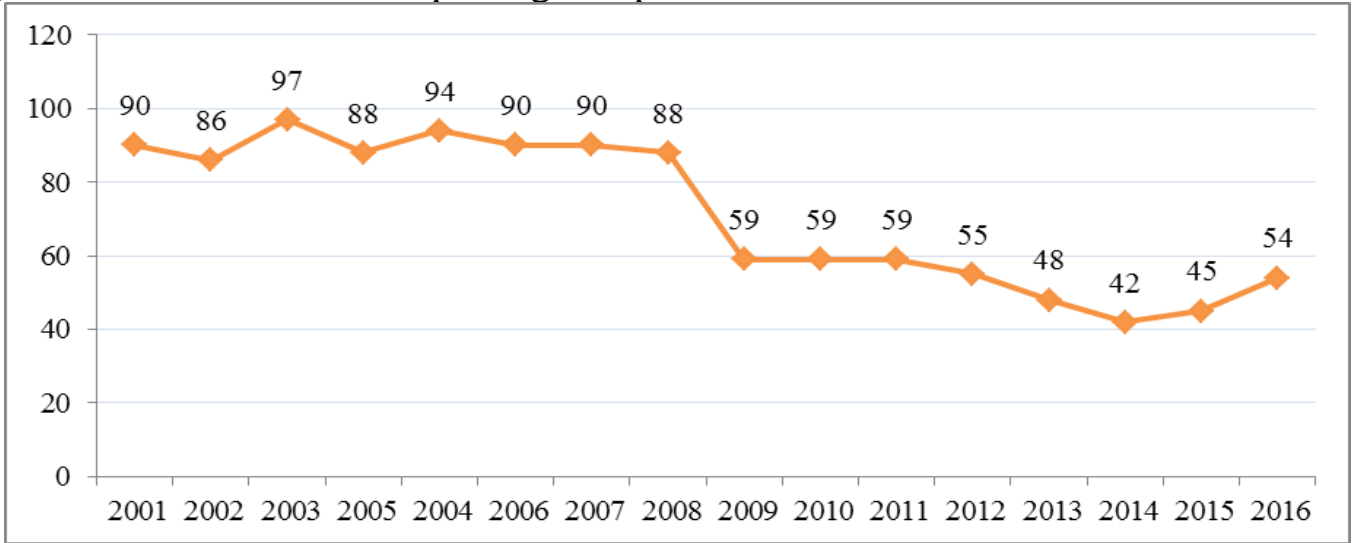

Source: adapted by Odair Alves, from Secretariat of Foreign Trade (SECEX) and Brazilian Ministry of Development, Industry and Foreign Trade data (2017)

Although there were a reduction both in deforestation rates and the number of timber companies, this activity will attend the "development" of the region, generating employment and income for the population, even if its exploitation is against to the conservation / sustainability process, since it seems to follow predatory and irregular forms, which can be considered the "exploitation pattern" for the Amazon Region. Possibly, these attacks will cause negative impacts on other natural resources, such as water supply, and, likewise, on the production of essential and vital elements, such as medicines and food, thus having a direct effect on the climate, which will be reflected in several scales. This may be linked to the question of insufficient inspections by Brazilian government, due to the great access difficulties to some parts of the forest.

Considering this, the Brazilian government must be connected with the necessary structures and resources to apply and validate the preservation laws. In this sense, forest management seems to be an alternative, which can reduce the gains in the early years of the logging process, but that should alleviate some of the environmental problems and ensure the existence and the economic sustainability, in the long run.

\section{THE TIMBER PRODUCTION PROCESS IN BREVES, ITS DECLINE AND THE "NEW" POSSIBILITIES OF EMPLOYMENT AND INCOME GENERATION FOR LOCAL POPULATION}

The from the 1960s to the early 2000s, the municipality of Breves lived the timber cycle, which was responsible for its territorial formation. However, according to Leão (2014), it is necessary to emphasize that the history of the city is directly linked to the business and the commercialization processes of several products taken from the forests 
by the river to different points of Brazil and abroad. To this author, extractive products represented one of the development vectors of the municipality, which, already in 1894, was one of the few settlements in the interior of the State in which the progress was already visible, standing out economically as a rubber producer (LEÃO, 2014, p. 57).

Figure 5 - Location of Breves municipality, at Pará State

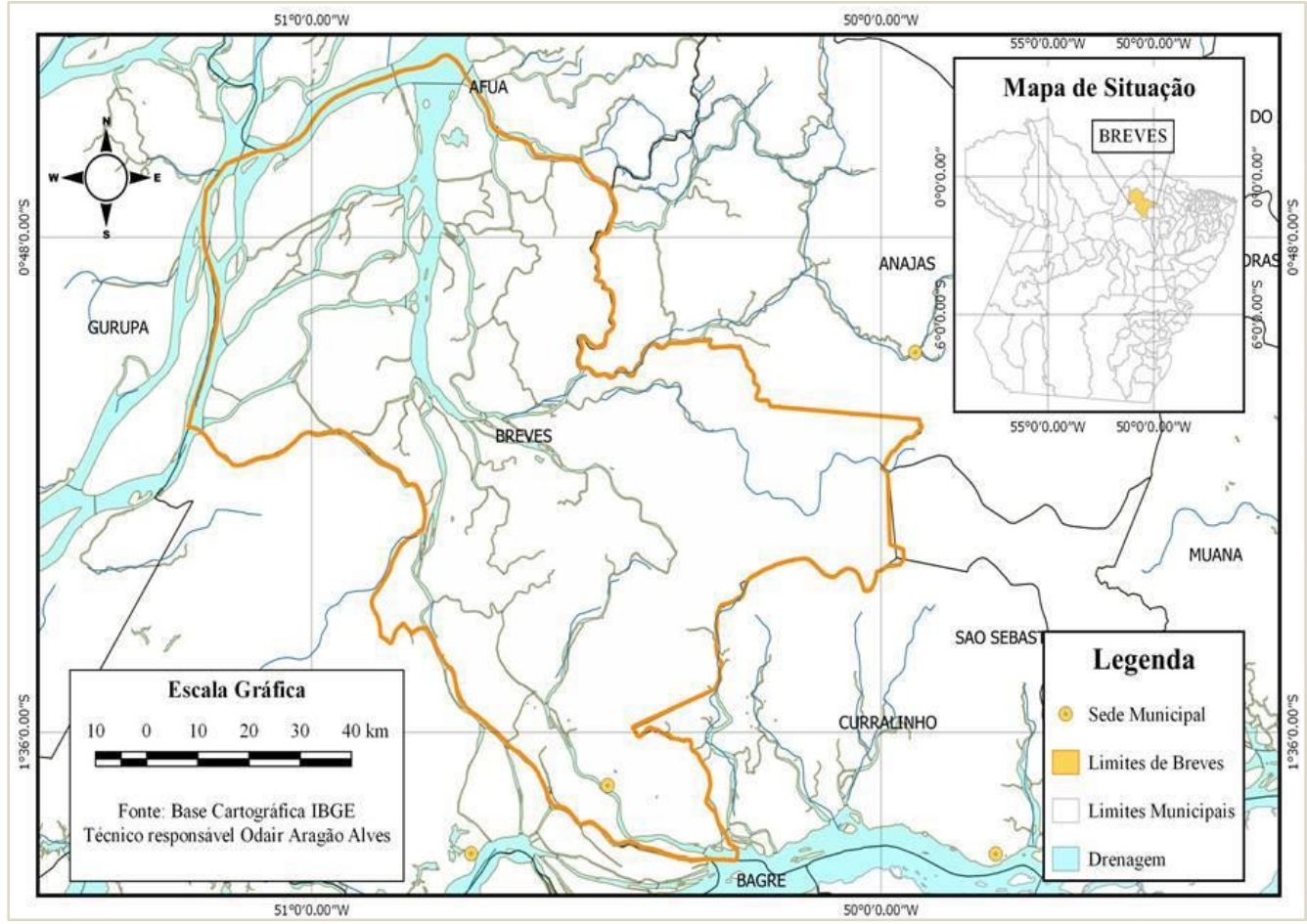

Source: made by Odair Alves (2016)

Thus, the production of space in Breves municipality was based, mainly, in the plant extractivism, in particular, the logging activity, which followed a singular pattern in this city, configuring it as an important timber pole. With evidence of timber decay, livelihood possibilities emerged more sharply in Breves' scenario, through the activities, which, during the full logging period, remained stagnant, such as agriculture and fishing. It is important to notice that a large part of the Amazonian population is composed of riverside dwellers (fishermen, agro-extractivists, collectors, etc.), who still find ways to supply their needs in the logging activity, while seeing the other activities as complementary forms of family livelihood, in view of the wealth of natural resources that can still be found in the region

The logging activity had great representativeness in Breves, showing itself relevant, in the perspective of the loggers, in its period of validity, because its production reached large consumer markets and, with this, generated thousands of jobs in the 
municipality. In Figure 6, we can observe the quantity of wood produced in logs, mainly destined to the external market.

Figure 6 - Amount of wood in logs produced in Breves, from 1989 to 2018 (in m³)

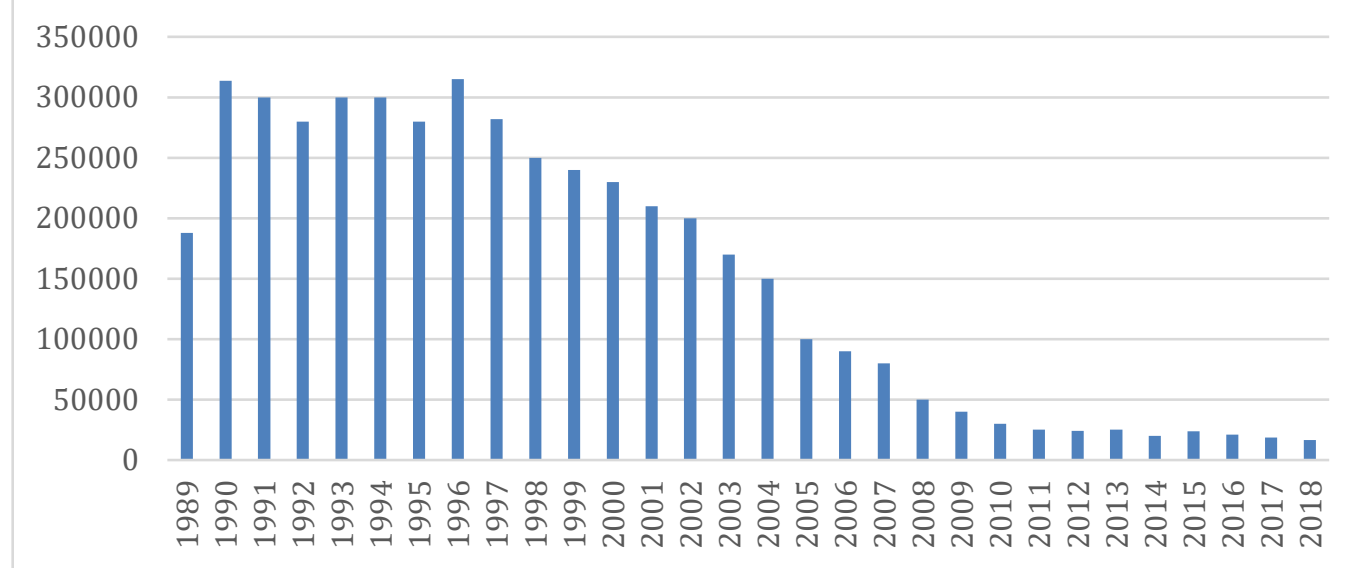

Source: IBGE (SIDRA)

This type of production gained notorious expression in the municipality of Breves between the 1980s and the first half of the 1990s, a period considered golden for the installation of timber mills, contributing to the strengthening of activity and to the occurrence of socioeconomic and territorial changes in the city. Among the main changes, we highlight the emergence of neighborhoods close to the locations of the timber companies, mainly resulting from the rural exodus, in which many of the families who worked in them were established. These living spaces had poor or non-existent infrastructures, which contributed to the emergence of social problems. With the signs of the closure of the factories, such as the considerable decrease in production, since the 1990s, were being developed new alternatives of employment and income, targeting the livelihood of the population, while others have been strengthened.

In economic terms, the decline of the timber production represented the reduction of a considerable percentage of the municipal revenue, mainly, from the decade of 2000 , period in which the massive closing of lumber units was marked and accentuated, bringing many instabilities to the local economy and leading to the intensification of various social problems.

It should be notice that, historically, the logging activity was stimulated for several decades in the Amazon, but in some cases, the exploitation of timber products occurred in a predatory way. In Breves, as well as in several municipalities of the Brazilian Amazon (and it is important to be noted and considered), the forms of exploitation are carried out 
in the different areas of the forests, both in floodplains and "dry lands", in which the removal of forest resources takes place in a different way, considering the characteristics of each type of land. In dry land areas, the exploration does not present itself as predatory character as in the floodplains, which present flooded properties, hindering the access of machines.

Figure 7 shows the decrease in the number of timber exportation companies in Breves, due to the mentioned factors.

Figure 7 - Number of exporting timber companies in Breves municipality, from 2001 to

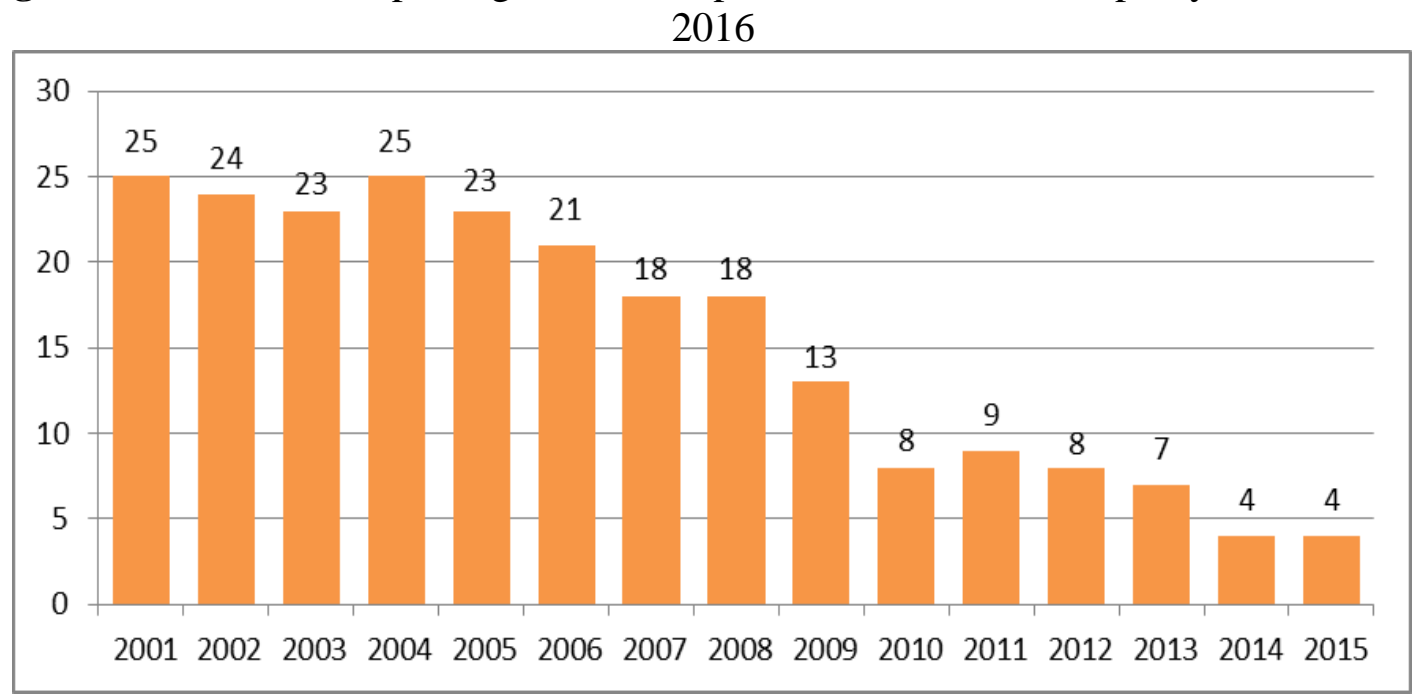

Source: made by Odair Alves, from Foreign Trade Secretariat data (2017)

This situation consolidated the unemployment rates in the municipality, especially from 2008. In 2010, the local population could not count on or raise hopes for changes in this scenario, forcing many people to promote other job opportunities or engage in other activities in order to enable their livelihoods. Soon, both primary and tertiary activities gain strength and become notorious, especially the last one, which is quite diversified in the city.

Considering the diversification of Breves production, both trade and services sectors were directly responsible for attracting a large number of people, who sought employment and livelihood opportunities. The popular commerce exists everywhere and coexists with the formal commerce shops, which specifically occupied the rim of Breves (Figure 8). Notice that many of these popular trades can generate environmental problems in the main river of the city, although not all occupation of areas, as the ones here mentioned, is synonymous with degradation. 
Figure 8 - Images of commercial activities on Breves' waterfront
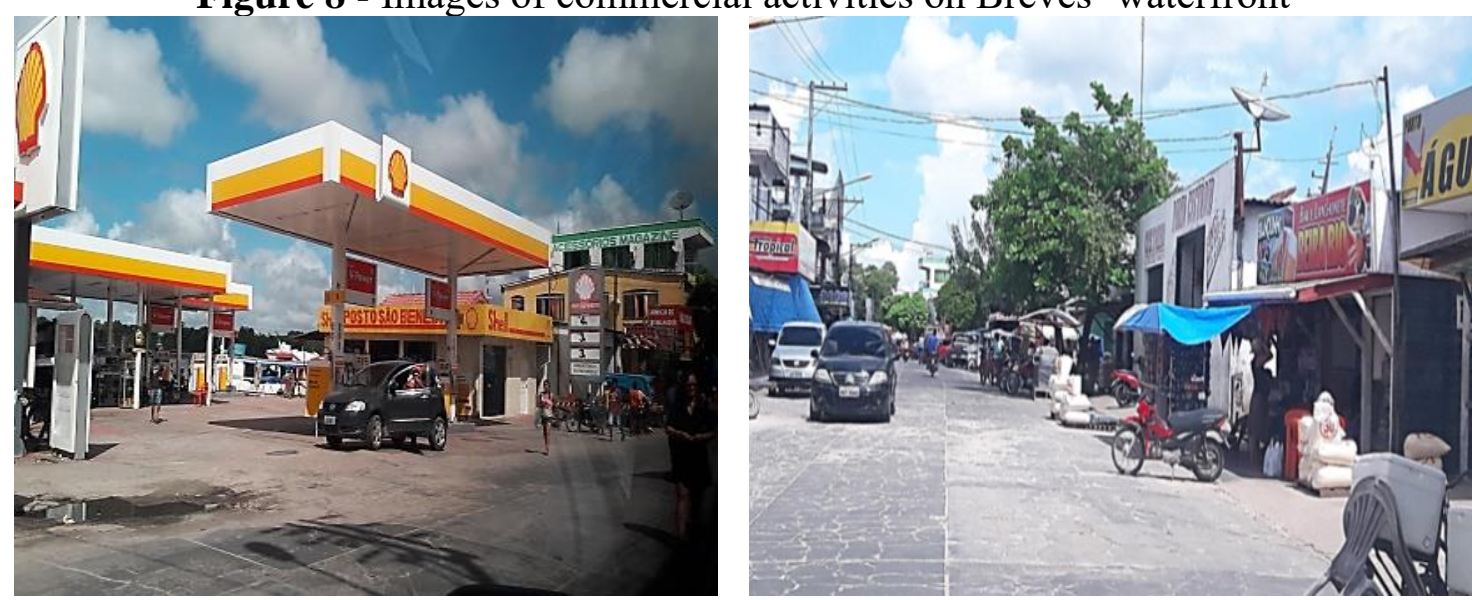

Source: Odair Alves' fieldwork photographic collection (2017)

In his work, Oliveira (2014) notes that the emergence of disorderly occupations and its negative repercussions have been intensified, mainly due to the bankruptcy of timber companies in the rural area of Breves:

Due to the deforestation control by environmental preservation agencies, many enterprises closed their doors in the countryside, leaving several people unemployed, which generated a migratory process to the urban area, culminating in the appearance of invaded areas in the city, shaking other sectors, like health, due to the proliferation of diseases caused by the lack of basic sanitation. The public security issue was also affected, given the increase in the levels of violence and crime caused by unemployment and the lack of public policies (OLIVEIRA, 2014, p. 3-4).

It is worth mentioning that, in addition to the search for jobs in the headquarters of the municipality, there is also the demand for commercial services to be offered there, some of which are not found in most municipalities of Marajó region, among them, the public banking services, such as those provided by Caixa Econômica Federal and Banco do Brasil, as well as those provided by private banks, such as Bradesco, Itaú, BMG and the State bank (BANPARÁ); both medium and high complexity health services that are offered by Marajó Regional Hospital; and higher education services, offered by Federal University of Pará and UNOPAR university, which are public and private institutions, respectively, as well as by the Federal Institute of Pará (IFPA).

The services offered in the city of Breves, be they productive, or distribution of goods, social and personal, among others, are fundamental in maintaining and improving the quality of life of the population. 
Figure 9 - Number of persons employed in both trade and services sectors in Breves, from 2011 to 2015

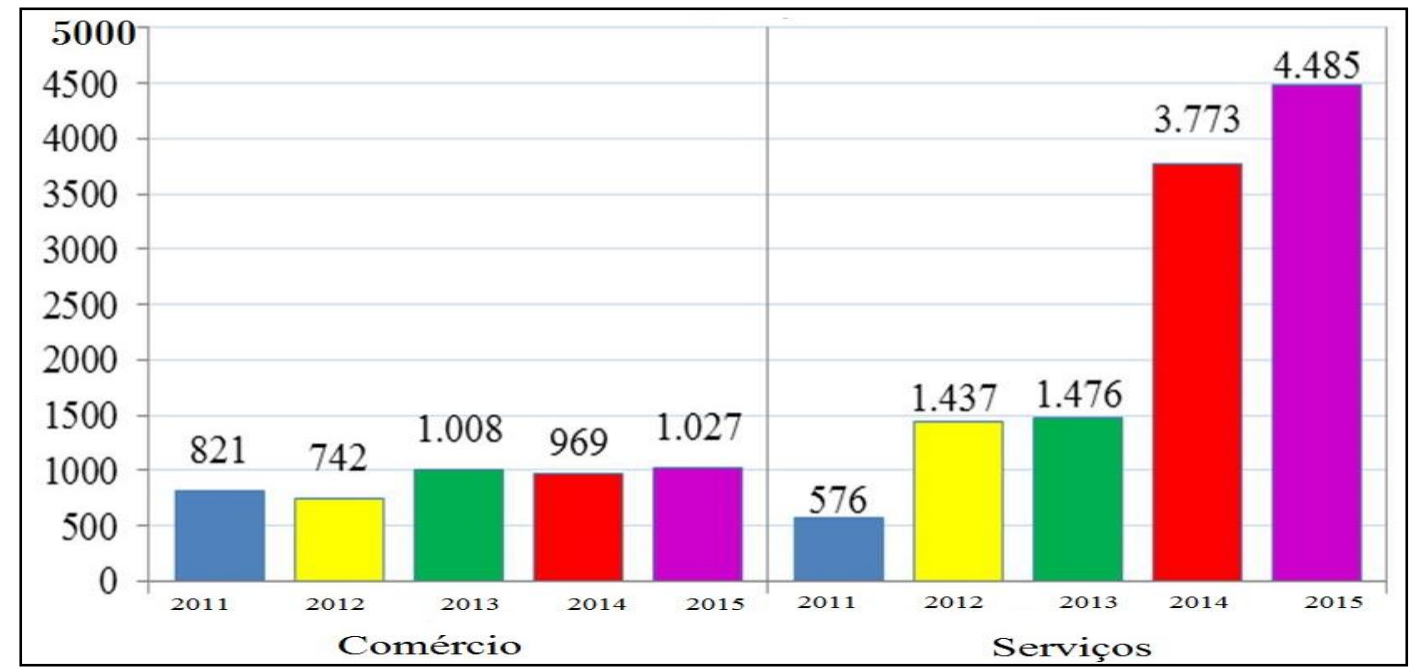

Source: RAIS / MTE and FAPESPA data (2017)

According to the data in the figure, these activities have shown expressive numbers, in the city of Breves, over the years, being responsible for income generation to a large portion of the population, since they are considered as developers of the Brazilian economy, as well as they are account for a considerable percentage of the national GDP. However, Breves' service provision is still very deficient, because there are many services that are non-existent in the city, such as those of the lottery houses, whose absence is quite remarkable and occurs for several reasons, such as lack of security, for example. Such deficiencies allow the emergence of third parties, which offer alternative ways and possibilities of providing these types of services.

However, it is important to mention that these activities constitute them as potential generators of employment and income in the municipality, mainly, from 2010, a period that marks the effective decline of the timber industry (Table 1).

Table 1 - Employment evolution in both trade and service sectors of Breves, from 2003

\begin{tabular}{ccc}
\multicolumn{3}{c}{ to 2015 (in \%) } \\
\hline Year / Activity & Trade & Services \\
\hline 2005 & +0.16 & +2.48 \\
2010 & +16.15 & +75.37 \\
2015 & +1.67 & -0.82 \\
\hline ource: Made by the authors, from CAGED data
\end{tabular}

In the period of timber industries closure in Brazil and, in particular, in Breves, between 2008 and 2009, it was evident the reduction in the number of employees in both 
commercial and service activities in the municipality. However, these statistics are positively changed, from 2010, after the accentuation of investments in these sectors, which started to absorb parts of idle labor, from the logging/processing companies.

With the resumption of timber activity in Breves, from the 1980s, trade represented possibilities of subsistence and, at the same time, its development. With this, the trade activity of the city came to figure as one of the main among the Marajó area, remaining as a regional pole, yet, in the present day. In addition to trade, the provision services emerged, accentuating and offering great diversity of facilities, generating jobs and boosting local economy, from the year 2000 .

However, the shaking caused by the decline of the logging activity in Breves directly reflected in trade sales, mainly to the timber industry supplying companies. It could be observed in the words of Interviewee A:

[...] by the time that the lumber companies were in full swing, at least here in our segment, $30 \%$ of our sales were to them. A very considerable percentage within any company. We had a very robust credit line. It was a very dynamic business; some loggers closed their accounts every 15 days and others every 30 days. As they worked according to the dollar, our closing was extremely dynamic [...] and because of the short term for us to receive, we gave a very high credit to these lumber companies (Interviewed trader A. Personal Report, 2016).

The dynamic of trade has been greatly altered, leading to the reduction in the number of direct jobs. The business entrepreneurs, in addition to making other investments in the organizational structure, aimed at serving a new kind of costumer, were forced to make a considerable number of layoffs. We can see it from the speech of a local businesswoman:

Currently, 22 employees. There was a reduction of about $50 \%$ in relation to the period of full timber activity. We had to reorganize ourselves a bit in our trade because the industries provided us with very large bills [...] a very large figure of merchandise and we started to serve "smaller" customers. We had to reorganize ourselves for our internal customer service that enters the store to buy, which buys a note. [...] we had to train our salesman a lot more (Interviewed businesswoman A. Personal Report, 2016).

The reports say that many customers, when possible, prefer to buy less and make cash payments, because, amid the timber crisis, many have been losing their trade credits. 
Gradually, the financing lines granted to the workers were being cancelled, as well as those of the timber companies, since they were in decline.

Also, according to the interviewee, local trade was strongly shaken by the closure of the timber industries: "[...] at the time that the lumber mills were at full steam, at least here in our segment, $30 \%$ of our sales were for lumber. A very considerable percentage within any company". For the small traders, in general, and for the interviewee, in particular, there were several negative legacies, of which the emphasis is the default: "[...] the purchases fell sharply, was that huge debt being negotiated slowly. So, it represented a strong brake in Breves' economy [...]".

There were profound changes after the closure and/or the migration of many of the timber mills, or, according to Haesbaert (2004), after the relocation of the companies and/or the easing of the productive activities. Thus, there were several strategies and land use forms in environments, in which timber economic activity predominated, generating resources for the maintenance, survival and, above all, the search for socioeconomic development.

The services offered supported such investments and contributed with local development, however such activities provoked, even, the real estate valuation, which became a significant form of commerce for many people, because the high (exorbitant) property values were related to the presence of banks, which facilitated the access to financial resources.

Despite the insertion of new service offers, Breves' service provision activities still need to improve themselves, in terms of quality and efficiency, mainly due to the absence of some services, that will meet the demands of the population, mainly, in health field, in which the lack of many specialties makes people have to seek care in Belém. Considering this situation, Breves' scenario began to face new social problems, since high unemployment rates contributed, in a way, to the increase of violence, because many unemployed entered the crime underworld.

However, some services have been showing a certain amount and diversity, like the educational, because higher education institutions, such as UNIP, UNICID, UNIASSELVI and UNOPAR (Figure 10), offer courses in distance and semi-face modalities, in addition to the courses offered by the government, such as the Continuing 
Initial Training Program for Basic Education Teachers (PROFIC) ${ }^{3}$, who are also responsible for stimulating a considerable number of neighbor cities' inhabitants.

Figure 10 - Images of Breves' private universities
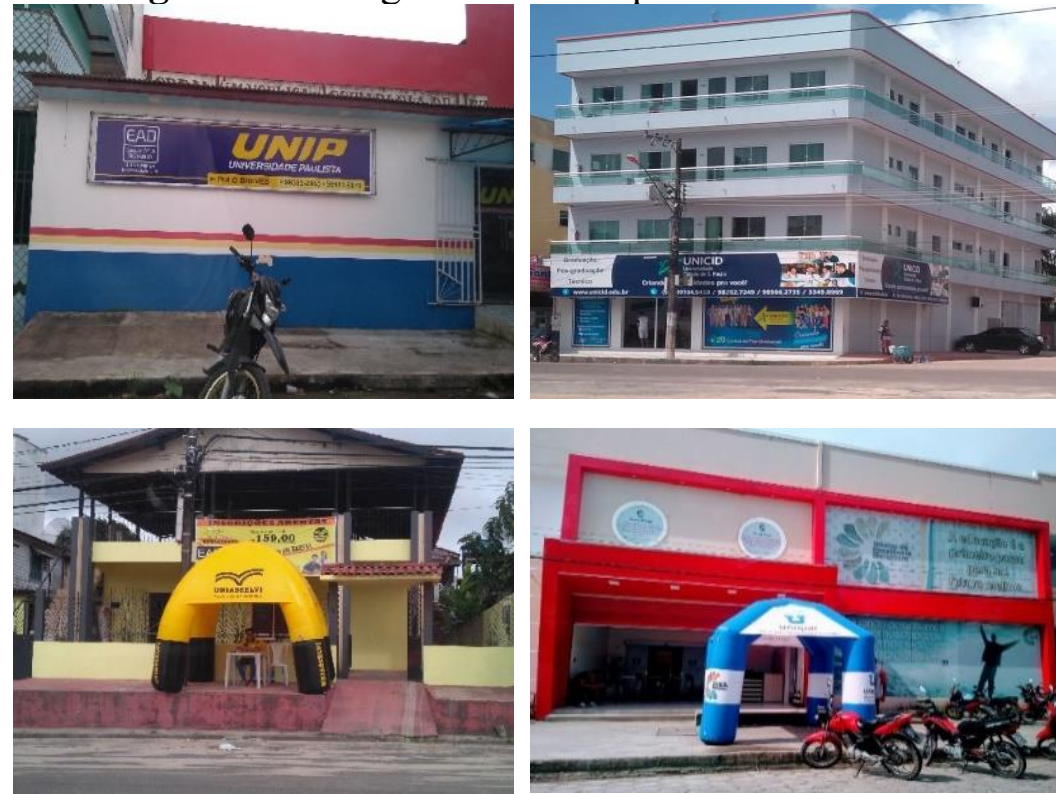

Source: Odair Alves' fieldwork photographic collection (2018)

In this sense, the expressive number of people who see the workforce qualification as a possibility of entering the labor market ends up going against Breves' reality, because it is perceived that such possibilities are decreasing every day, since the negative reflection of the lack of employment opportunities has been lingering over time, causing an uncertain future. The consequences of the absence of jobs are already remarkable: a significant number of people available to the labor market are unoccupied; others are migrating to other municipalities and states; and violence rates, which may have to do with the lack of employment, are increasing.

River transport services, which represent the main form of mobility for Breves' population, mainly towards the cities of Belém and Macapá, are regularly provided by shipping companies, with an average duration of 13 hours ${ }^{4}$, establishing the link BrevesBelém-Macapá. This service has been expanding and diversifying over the years, in order to optimize the crossing between Breves and Belém. In this sense, catamaran-type vessels

\footnotetext{
${ }^{3}$ PROFIC Program replaced the Brazilian's National Basic Education Teacher Formation Plan (PARFOR).

${ }^{4}$ The tidal regime directly interferes in the trips to Belém and Macapá, which can last around 15 hours or more. It is worth mentioning that this time is based on ship and ferryboat vessels.
} 
were deployed to transport only passengers, reducing travel time to approximately six hours.

Among the main shipping companies, which have been active for decades, we highlight São Domingos, Custódio, Leão do Marajó and Bom Jesus, the latter having the monopoly on Breves-Belém catamaran river transportation. It is essential to mention that the regular trips make stopovers in Portel, Bagre and Curralinho municipalities, in Pará's Marajó region, but they do not make trips to the State of Amapá, which are carried out by other companies.

The shipping companies assume an important role in the local economic development, because they supply the trades of Breves and neighboring cities with goods coming from the metropolitan regions of Belém and Macapá, besides making people's transportation, generating, also, numerous informal jobs.

After the decline of logging activity, it was noticed the presence of a quite high number of constructions in the city, as houses, trades and shops, along the years. This change corroborated the comparative analyses between both previous and current economic period of Breves, which is based on trade, services and other forms of subsistence, noting that the standards and quality of life of the population have improved.

With the closure of the timber companies, many people started to promote investments, in order to work autonomously, emphasizing that many of those who had employment with such companies also joined the civil service, mainly in the area of education. In Breves, the civil service is very grounded in both education and health municipal departments, which absorb large numbers of labor and guarantee employment and income generation, functioning as the main driver of the municipality's economy.

In 2015, among the 4,359 active employees of Breves City Hall, 2,908 were full in the Education Department and 782, in the Health Department. The quantitative of these departments include employees and contractors' workers, which corresponds to approximately $85 \%$ of the total of employees of the agency. Figure 11 shows the evolution in the numbers of employees of the municipality and gives us the idea of how this body is responsible for generating a considerable amount of jobs to local population. 
Figure 11 - Number of permanent employees of Breves City Hall, from 2000 to 2015

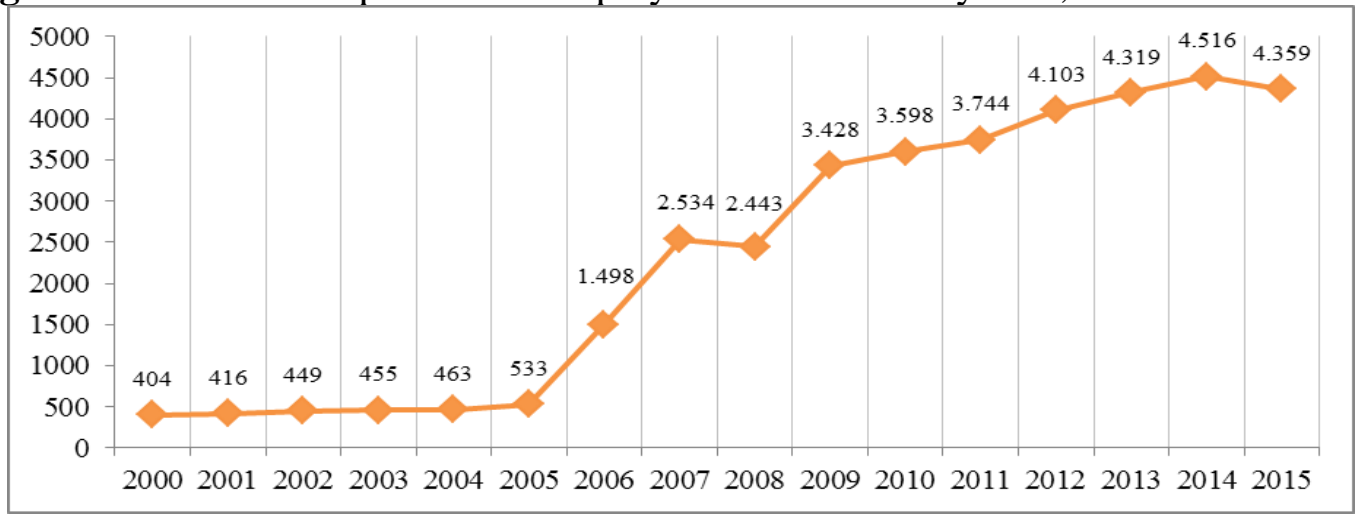

Source: Website data (www.breves.pa.gov.br/transparencia/) (2018)

Given the information of the figure, we can understand that the city is strongly energized by the large amount of people, who have some kind of employment relationship with local City Hall, which leads us to realize that this body is directly responsible for offering employment and income to the population, demonstrating that the municipality has low capacity to generate own revenue and aggregate resources, to provide subsidies to improve the quality of life of its people.

As mentioned, there were some investments in the construction of stores and commercial establishments, however, in addition to the increase in the possibility of generating employment and income, it was noticed that this phenomenon provoked large real estate speculation. Thus, the valuation of the properties was monitored and encouraged by banking institutions, which facilitated the purchase and sale operations, interfering directly in the municipal revenue, especially the increments of municipals' property tax (IPTU) and real estate transfer tax (ITBI).

The construction industry gained space in Breves, amid the decaying of timber activity, and came to have great importance in the city, providing jobs and income. Despite this, today, the activity is stagnant. There were numerous factors that contribute to this, among them, the real state overvaluation, mainly in the central part of the city, and the difficulties in obtaining financing, along with bank institutions, whose banking fees are not as affordable at present.

Figure 12 shows the total number of admissions and dismissals in the construction sector, from 2007 to 2016 . These data show a negative variation between the two rates, but we can still consider the total number of admissions significant, considering the scenario of uncertainties that took place in the municipality after the closure of the timber 
companies. It is common for the construction sector to comply with admissions and dismissals dynamics.

Figure 12 - Number of admissions and dismissals in Breves' civil construction activity, from 2007 to 2016

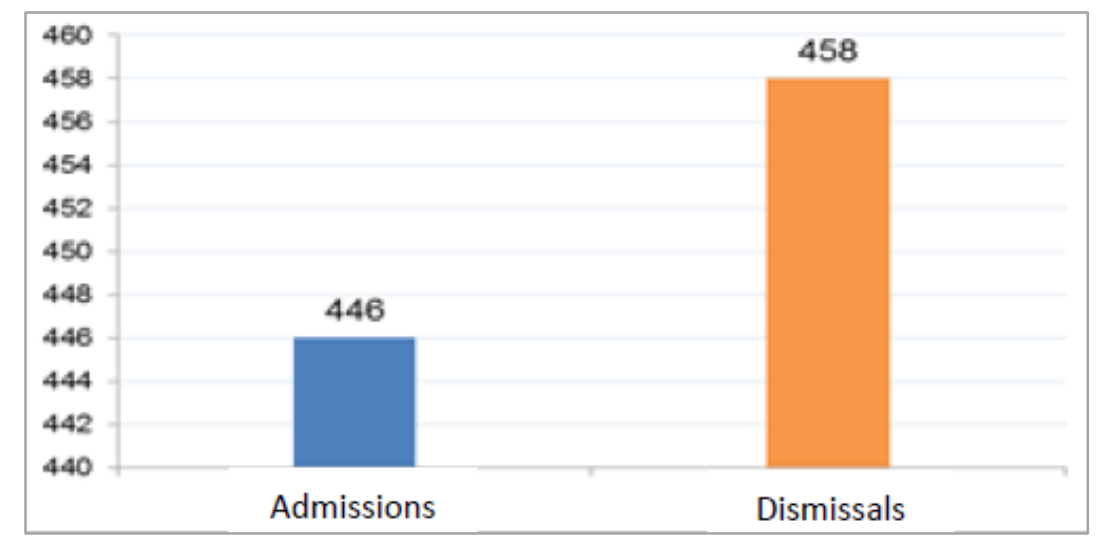

Source: made by Odair Alves, from Brazilian Work Statistics Dissemination Program (PDET) / MTE data (2018)

In addition to the construction of shops and commercial properties, we highlight the housing market of Breves, which contributed to the strengthening of the construction industry. Many companies promoted the erection and commercialization of residences, including, due to the implementation of government housing policies, from the support of the largest real estate financier in Brazil, Caixa Econômica Federal, which has a unit in the city.

\section{FINAL CONSIDERATIONS}

The logging activity caused social, economic and environmental repercussions on Breves' population, especially regarding the development process of the city. During its period of greater production, this economic activity contributed to the insertion of the municipality in both national and international markets, since the production of its main timber companies obeyed export parameters. Likewise, the changes in the population's living standards were representative, due to the number of jobs offered by the companies, which were installed in the municipality, over the years.

For several decades, Breves' economy was based on extractivism, mainly forestry, although such activity was technically little developed, which directly reflected in both exploitation and processing of its products. However, among the municipalities in Pará, the city was one of the largest and oldest latex producing / exporting poles, having the 
United States as one of the main consumers. Parallel to this activity, trade and the flourishing timber industry have stimulated a considerable population influx to the municipality, as well as the access to banking and health services, among others.

The installation of the timber companies in Breves meant, for local population, great possibilities of jobs, causing changes in the physical space and bringing improvements to the living conditions of the people of the city, that began to organize, very slowly, to meet the demands of the urban population, which increased, due to job offers.

However, as in many of the Amazon municipalities, the logging process in Breves followed a cycle, which began in the 1960s and lasted until the mid-2000s. Evidently, like any cycle, this production lived moments of ascendancy, reached its apogee and, after all, knew its downfall, because, as we know, this is the dynamics of economic activities, which exploit finite resources.

Breves economic production processes date back to the first decades of the twentieth century, period in which the municipality had, as main economic base, the latex extraction, activity developed on a large scale, at regional level, and spread by several Marajó region municipalities. Soon, Corcovado village ${ }^{5}$ became the main place of latex production, obtaining relevance in different scales, during World War II period.

The latex production in Corcovado village had its golden period between the years of 1940 and 1960, lasting until the 1970s, when the logging activity had already emerged and accompanied the end of the latex production cycle. During the latex production period and the beginning of the timber activity, rice cultivation also stood out, including Breves among the main rice exporters in Brazil, production that overlapped, including, latex and wood.

The trajectory of the logging activity in Breves and region was extremely striking, from the territorial and socioeconomic points of view. During the development of this industry, the supply of jobs was accentuated, although for a large part of Breves' population these jobs represented only one way of subsistence, that is, surveillance.

Over the years, it was realized that the activities of the wood industry in the Amazon aimed only to settle in a certain area, from which it could take advantage of natural resources to the exhaustion limit, to then transferring to other areas, continuing its

\footnotetext{
${ }^{5}$ Settlement that is located approximately $5 \mathrm{~km}$ from Breves by land.
} 
purpose, specifically, remaking the cycle of exploitation, and legitimizing the decay of the activity.

During the period when the timber industry played the leading role in generating income for Breves' population, few investments were made in other subsistence forms. Trade and service activities had little visibility, at regional level, mainly among neighboring municipalities, but this reality began to change, from the 2000 s, when the indications of the crisis in the forestry sector gained awareness and expression, highlighting, in this sense, the economic context of Breves municipality.

Since the crisis in Breves, job vacancies have expanded in both service and trade activities, making it possible to establish several informal occupations, in addition to strengthening many of the existing ones. The production of local space turned to meet a "new" organization, resulting from the arrival of many national immigrants, who came to occupy positions in banking institutions and hospitals mainly, like the Regional Hospital of Marajó, in addition to jobs resulted from investments in hotels and the construction of residences and other forms of housing, which began to develop in the city.

Currently, There is only one wood production company operating in the municipality, focused on log sawing and planing. Despite the decay of the logging industry, we can still observe the importance of this activity in Breves, as main or supplementary source of income on monthly budget of many families, who live in the boreholes and rivers of the city, evidenced by the presence of several sawmills, especially the production of broom handles.

Given the scenario of uncertainties that characterized the municipality of Breves after the decline of logging activity, from the late 2000s, and with the absence of another activity to replace it, several strategies were employed, in order to guarantee the generation of employment and income to the population, that is, their subsistence, some of which materialized and others were gradually strengthened, in order to alleviate the problems arising from the timber industries closure.

Fishing and agriculture activities, for example, were poorly advanced during logging period. In some cases, both remained stagnant, due to the fact that many of the people who worked as fishermen and as farmers began to work in the logging companies, developing both fishing and agriculture only as a form of family subsistence.

Currently, however, such activities, although receiving little or no investment for their expansion, represent the livelihood of many riverside families, aggregating the 
values obtained from these practices to the gains obtained from local small businesses and government welfares.

Regarding Breves' agriculture, the urban population resents itself on the lack of some products that could be produced in the city, but are acquired from the Metropolitan Region of Belém, which provides fruit, vegetables and vegetables to the city, in a few days of the week, considering the forms of transportation and the distance between the two cities.

New strategies, to be implemented by the different governmental spheres, are necessary, aiming at ensuring the development of both local populations and municipality itself, that may reflect positively on the economies of other Marajó region municipalities. Such policies should not repeat those of the timber activity period, which benefited only a few groups; on the contrary, they should seek to contemplate the reality of local socioeconomic development and ensure better living conditions for the people of Breves municipality. Similarly, these strategies should try to bring a quick financial return and warrant the supply of numerous jobs to the population. Such a logic may involve rescuing traditional activities, such as fishing and agriculture, which have been historically undervalued, acquiring another status, currently, despite the absence of investment. The abandonment of these practices in the past, by the riverside population, resulted on the migration of these workers for logging business.

The role of local government in stimulating economic development and growth, seeking the generation of jobs and income is indispensable and essential, in order to ensure better living conditions for Breves' population, as well as the application of greater volumes of investments in infrastructure, through public programs and policies, which can also promote social equity.

\section{REFERENCES}

CASTRO, E. Dinâmica socioeconômica e desmatamento na Amazônia. Novos Cadernos NAEA, Belém, v. 8, n. 2, p. 5-39, 2005.

CASTRO, E. Políticas de ordenamento territorial, desmatamento e dinâmicas de fronteiras. Novos Cadernos NAEA, Belém, v. 10, n. 2, p. 105-126, 2007.

FEARNSIDE, P. A floresta amazônica nas mudanças globais. Manaus: INPA, 2003.

HURTIENE, T. Agricultura familiar e desenvolvimento rural sustentável na Amazônia. Novos Cadernos NAEA, Belém, v. 8, n. 1, p. 19-71, jun. 2005. 
LEÃO, D. do S. de S. O porto em narrativas: experiências de trabalhadores, moradores e frequentadores da área portuária de Breves-PA (1940-1980). 2017. Dissertação (Mestrado em História) - Programa de Pós-Graduação em História Social da Amazônia, Universidade Federal do Pará, Belém, 2014.

MARGULIS, S. Causas do desmatamento da Amazônia brasileira. Brasília: Banco Mundial, 2003.

MENEZES, M. de N. A.; GUERRA, G. A. D. Exploração de madeiras no Pará: semelhanças entre as fábricas reais do período colonial e as atuais serrarias. Cadernos de Ciências \& Tecnologia, Brasília, v. 15, n. 3, p. 123-145, set./dez. 1998.

OLIVEIRA, H. S. de; Estudo de caso no município de Breves: da desestruturação produtiva ao risco social (2000-2010). In: SILVA, J. M. P.; SILVA, C. N.; CHAGAS, C. A. N. (Org.). Geografia, segurança pública e ordenamento territorial. 1. ed. Belém: GAPTA/UFPA, 2014. p. 103-128.

VERISSIMO, A.; LIMA, E.; LENTINI, M. Polos Madeireiros do Estado do Pará. Belém: Imazon, 2002. 